\title{
Effectiveness of Video Learning Development Announcing
}

\author{
Fifit Fitriansyah \\ Universitas Bina Sarana Informatika, Indonesia \\ fifit.ffy@bsi.ac.id*
}

\begin{abstract}
The learning process is the most important activity. Therefore, the success of achieving learning objectives depends on how the learning process takes place effectively. In improving the effectiveness of learning, one of them uses learning media in the form of learning videos. This study aims to see the effectiveness of the announcing learning video development model to improve student's learning outcomes. The research method used is research and development with qualitative descriptive data analysis techniques and descriptive statistical analysis. The assessment rubric is used as a performance assessment test to see learning outcomes. The results of this study indicate that student's learning outcomes after using announcing learning videos are as much as $84 \%$ increase compared to students who do not use announcing learning videos as much as $16 \%$. Thus, the development of announcing learning videos is considered effective in improving student's learning outcomes.
\end{abstract}

Keywords:

Effectiveness of Development, Learning Videos, Announcing

This is an open access article under the CC-BY-NC license.

\section{INTRODUCTION}

Learning is the process of interaction of students with educators and learning resources in a learning environment. The context of interaction in the learning process is social interaction, namely the relationship between individuals and groups. In this case, the teacher as an individual interacts with a group of students (Chalil \& Latuconsina, 2008). Learning is a process carried out by the individuals to obtain a new behavior change as a whole, as a result of the experience of the individual itself in interaction with the environment. In other words, learning can be said as an effort to obtain changes in behavior in individuals obtained from the process of interaction with its environment (Tim
Pengembang Ilmu Pendidikan FIP-UPI, 2007). Thus, the learning process is the most important activity. Therefore, the success of achieving learning objectives depends on how the learning process takes place effectively.

An effective learning process is inseparable from the role of the learning resources used. Selflearning resources are materials that include play tools that are used to provide information and various skills to students in the form of reference books, storybooks, pictures, resource persons, video tutorials, and other cultural objects.

If viewed from its utilization, AECT distinguishes learning resources into two types, namely: (1) learning resources that are deliberately designed 
(by design) to be used in learning activities to achieve certain learning goals. Learning resources that are designed can be in the form of text, textbooks, slides, films, videos, etc. that are deliberately designed to help achieve certain learning goals. (2) learning resources that are utilized (by utilization) to help achieve certain learning goals, for example, community leaders, shops, markets, and museums (Darmono, 2006).

One supports the learning process is the use of instructional media, one of which is a learning video. The video itself is a series of moving images that combine two elements, namely audio and visual. The existence of an audio element allows students to be able to receive learning messages through hearing, while the visual element allows creating learning messages through visualization.

Learning videos in this position function as learning media. Where learning media occupies an important position as one of the components of the learning system, without the media, communication will not occur, and the learning process as a communication process also will not be able to take place optimally.

The selection of video as a learning resource in the form of instructional media in announcing learning is considered relevant and effective, considering that learning requires direct examples that are sometimes difficult to practice by the educators.

Announcement learning is one of the courses for broadcasting students at the Bina Sarana Informatika communication academy, where this course teaches students about the mastery of sound processing techniques undertaken by students to become broadcasters, both on television and radio. A theoretical content of only $30 \%$ and the remaining $70 \%$ of direct practice requires students to be proficient in presenting an event as a broadcaster, both television, and radio.

Referring to the background of the problem above, it is necessary to use announcing learning videos to improve student's learning outcomes. With the development of announcing learning videos, it is expected to be able to help students in practical learning, to improve learning outcomes. For this reason, the formulation of the problem in this study is how the effectiveness of learning video development models.

\section{THEORETICAL PERSPECTIVES}

\section{Concept Development Model}

Concept Development Model Development is the application of new scientific discoveries into the practice of either creating new products, developing products, or replacing the raw materials of these products, with the hope of improving existing quality (Zaharuddin, 2006).

Little John in Wiryanto argues that the model is "in a broad sense a term model can apply to any symbolic representation of things, processes or ideas" (Wherein in a broad sense. The model means something that can be applied from any symbolic representation of a process object or idea) (Wiryanto, 2004) 
Thus, the development of models is a scientific activity in the form of abstraction of an object to create a new product based on the rules and theories of science that has been proven true by showing direct and indirect relationships and reciprocity regarding cause and effect.

The purpose of developing a model in learning is to solve learning problems, improve the quality of learning activities, and improve the conditions of the learning environment (Suparman,2010). The development model is the basis for developing products to be produced. Development models can be in the form of procedural models, conceptual models, and theoretical models.

The concept model developed refers to the concept of developing learning models that are commonly used in learning development. There are five types of learning development model commonly used in education, namely: (1) Instructional System Design Model (Gagne 1979); (2) Instructional System Development Procedure Model (PPSI); (3) Dick and Carey Model; (4) AT\&T Instructional Development Model; (5) Instructional Development Model (Suparman, 2010). The development of a model used in the development of this learning video is to use the Dick and Carey development model which is often used in the development of learning which consists of ten stages as illustrated in the following chart:

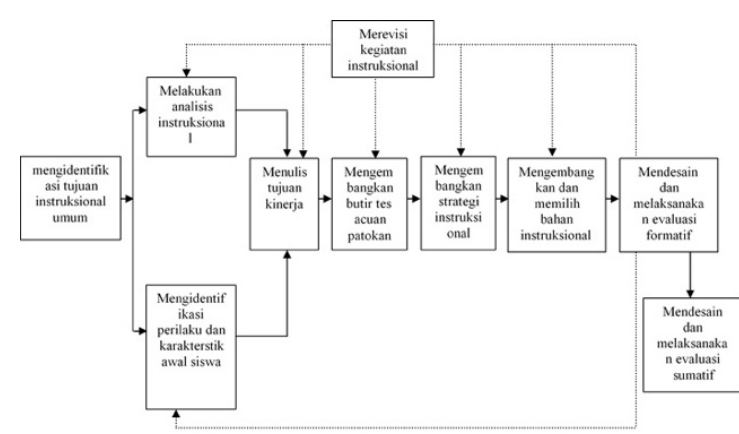

Figure 1: Dick and Carey Model (Suparman, 2010)

\section{Learning Media}

The word media comes from the Latin, "medium," which means middle or introduction (Arsyad, 2004). The term learning itself is used to indicate an educational effort that is carried out intentionally, with goals that have been set before the process is carried out and whose implementation is controlled. Thus, learning media are all things that are used to channel messages and can stimulate thoughts, feelings, attention, and will, the learning so that it can encourage the process of learning that is intentional, purposeful, and controlled (Miarso, 2009).

The benefits of using media in the learning process are: (1) the learning process can occur in two directions, so that, it becomes more interactive; (2) the learning process becomes more efficient; (3) the learning process becomes more interesting, and it is expected that with the learning media learning quality of students will increase; (4) the place where the learning process takes place can occur anywhere and anytime; (5) in this case, the role of the educator functions as a facilitator (Widodo \& Jasmadi STP, 2008). Arsyad stated that several 
criteria must be considered in the selection of media including, (1) following the objectives to be achieved; (2) appropriate to support learning. The content that is like facts, concepts, principles, and generalizations; (3) practical, flexible, and enduring; (4) skilled teachers use it; (5) grouping of targets; (6) technical quality (Arsyad, 2004).

Criteria in the selection of instructional media also need to pay attention to topics, teaching materials, content relevant to the curriculum, real concepts, sequencing, effects, and colors that have been tested for truth. Thus, the learning media will stimulate students to remember both the knowledge they already have and new knowledge. Also, Besides, with learning media, students become more active by doing interaction and feedback both towards the teacher, and other students. Thus, the more learning objectives are helped to use the media, the better the media.

\section{Learning Videos}

The word video comes from Latin, which means "I see." Video is a processing technology that uses electronic signals that represent a motion picture. The application that can be seen from the video is television. However, video can also be applied in the fields of engineering, science, production, and security. Furthermore, video can also be called videotape, video recorder, and video player (Binanto, 2010). Video is also a collection of the display from frame by frame very much. Where when the frame is rotated at a speed of 20 frames / second, what will be seen is only the transfer of frame by frame, which is a video display with moving images. This is due to the limitations of the human eye senses, which cannot capture the transfer between frames. The rotational speed possessed by the video to display images on a video is known as the frame rate (Westriningsih, 2010). The learning video itself is a medium that is intentionally designed system that refers to a predetermined curriculum and in its development applies to the principles of learning, so that the existence of a learning video can stimulate students in understanding learning material more easily and attractively. The advantages of learning videos include: (1) Can stimulate the effects of motion; (2) Can be given additional sounds and colors; (3) its use is easier; (4) Does not require special expertise in its presentation; (5) Can be seen after being recorded, so that the results can be known immediately; (6) Cheaper manufacturing costs; (7) Can be duplicated in the form of VCD / DVD; (8) Can be played back, stopped briefly, and so on (Mirmani, 1996: 81). The shortcomings of learning videos include: (1) Requires special equipment in its presentation; (2) Requires electricity to flow; (3) If compressing is done, the video quality will decrease. Thus, video is a medium used in the learning process. The use of video is expected to help the learning process when the learning content is related to the practice of direct experience.

\section{METHOD}

In seeing the effectiveness of the development of the model, this research used the Borg and Gall 
research and development (R\&D) research and development method, and for the effectiveness of the model using a performance assessment in the form of an assessment rubric. For this reason, the assessment rubric used in a performance assessment contains assessment criteria for the results of a performance task. The rubric uses four grading scales (range 4-1).

The data that has been obtained is then analyzed the first by formulating it into quantitative data, which is then descriptively qualitatively. The formula used is as follows:

$$
\left(\frac{\sum x}{n}\right)
$$

Explanation:

$\sum \bar{x}$ : The total score divided by the average number of indicators

$\mathrm{n} \quad=$ Many questions

\section{FINDINGS AND DISCUSSION}

Design of Development and Manufacture of Video Learning Products Announcing Design.

Product development in this study begins with the research stage and data collection. At this stage, data collection was carried out in the form of 1) a literature study related to the steps of product development, including approaches in designing videos and ways to design products, 2) collection of material in the form of material to be produced for the development of announcing learning video products.
The development of learning videos in this study uses a product development in the form of Ulead Video Studio 11 and Adobe Premiere software used in the video editing process. At the production stage, the developer refers to the script and storyboards that are made in advance to facilitate the production process. In the development of this announcing learning, the video has three stages, namely pre-production, production, and post-production.

Development of the Initial Product Form (Development Preliminary Form of Product)

There are Two materials developed in this announcing learning video, namely announcing techniques and techniques. Yoga This is because both of these materials require visual examples of direct motion that cannot be explained in theory and are the Two core material of the announcing subject.

The effectiveness of the announcing learning video development model has done through interviews, observations, and test giving after the respondent sees the announcing learning video. The test given is in the form of a performance assessment, in which the respondent is given several some many questions which can then be answered by practicing following the benchmark reference or criteria (rubric) that the developer uses in assessing the performance of the respondent (student). The following are the results of student performance assessments based on assessment criteria on average: 


\section{Table 1: Results of Respondent Performance assessment tests}

\begin{tabular}{|l|l|}
\hline Criteria Value & Average \\
\hline Pronunciation & $93 \%$ \\
\hline Respiratory Technique & $98 \%$ \\
\hline Command Technique & $57 \%$ \\
\hline Sitting Technique of Yoga & $100 \%$ \\
\hline The Essence of Yoga & $76 \%$ \\
\hline Percentage of Learning Outcomes & $84 \%$ \\
\hline
\end{tabular}

Based on the assessment of learning outcomes tests using performance assessment, it was found that the percentage of student's learning outcomes after using announcing learning videos was as much as $84 \%$ compared to students who did not use announcing learning videos as much as $16 \%$.

\section{CONCLUSION}

Based on the increase in student's learning outcomes after using announcing learning videos is as much as $84 \%$ of student's learning outcomes increased compared to those who did not use announcing learning videos as much as $16 \%$. Thus, based on the percentage acquisition data, it can be concluded that the effectiveness of the announcing learning video development model can improve the student's learning outcomes so that this model can be used and disseminated to announcing learning in other classes.

\section{REFERENCES}

Arsyad, A. (2004). Media Pembelajaran. Jakarta: PT Raja Grafindo Persada.

Binanto, I. (2010). Multimedia Digital: Dasar Teori dan Pengembangannya. Bandung: C.V. Andi Offset.

Chalil, A., \& Latuconsina, H. (2008). Pembelajaran Berbasis Fitrah (1st ed.). Jakarta: Balai Pustaka.

Darmono. (2006). Perpustakaan Sekolah Pendekatan Aspek Manajemen dan Tata Kerja. Jakarta: Grasindo.

Miarso, Y. (2009). Menyemai Benih Teknologi Pendidikan. Jakarta: Kencana.

Suparman, M. A. (2010). Desain Instruksional (2nd ed.). Jakarta: Universitas Terbuka.

Tim Pengembang IImu Pendidikan FIP-UPI. (2007). IImu dan Aplikasi Pedidikan, Bagian 1 IImu Pendidikan Teoretis. In Handbook (2nd ed.). Bandung: PT IMPERIAL BHAKTI UTAMA.

Westriningsih, etc. all. (2010). Panduan Praktis Pinnacle 12 untuk Pengolahan Video. Yogyakarta: C.V. Andi Offset.

Widodo, C. S., \& Jasmadi STP. (2008). Panduan Menyusun Bahan Ajar Berbasis Kompetensi. Jakarta: PT Elex Media Komputindo.

Wiryanto. (2004). Pengantar IImu Komunikasi. Jakarta: PT Gramedia Widiasarana Indonesia. Zaharuddin, H. (2006). Menggali Potensi Wirausaha. Bekasi: CV. Dian Anugrah Prakasa. 